\title{
Police Violence and Its Public Support
}

\author{
By William A. Gamson and James McEvoy
}

\begin{abstract}
The paper analyzes two models of social support for totalitarian social movements, the mass society model, and the class conflict or interest group model. Using national survey data, the authors formulate and test the implications of each of these models in terms of generating support for police violence among the mass public. With the exception of a positive relationship between education and rejection of police violence, the mass society model is not well supported by the data examined by the authors. Generally strong support is present for the class conflict model.
\end{abstract}

William A. Gamson is professor of Sociology and a staff member of the Center for Research on Confict Resolution at the University of Michigan. He is the author of Power and Discontent for which he received the 1969 Sorokin Award of the American Sociological Association. He is also the author of a teaching game, SIMSOC: Simulated Society and a forthcoming book with André Modigliani, Untangling the Cold War. He has written on community confict and coalition formation; for work in the latter area, he received the 1962 Socio-Psychological Prize of the American Association for the Advancement of Science (AAAS). His current work involves a study of the carecrs of relatively powerless groups that have challenged the American political system since 1800.

James McEvoy is assistant professor of Sociology at the University of California, Davis. He is the author of a forthcoming book, Radicals or Conservatives? The Contemporary American Right and an editor, with A. Miller, of Black Power and Student Rebellion. He served as a special consultant to the National Commission on the Causes and Prevention of Violence.

We are indebted to John P. Evans, David Segal, Edward Laumann, and Leon Mayhew for their criticisms of an earlier draft of this paper, and to Richard Juster for his suggestions and assistance in getting our data in and out of the computer. 
D

URING the winter of 1970 , a United Press International correspondent was taken into custody by police and held for twenty hours. $\mathrm{He}$ had been covering a student riot in Santa Barbara. During the period he was detained he was neither formally charged nor allowed to make a phone call. "War correspondents," California Governor Ronald Reagan explained with a grin, "have to realize that sometime they are going to get it. . . . He should be happy he was captured by the good guys." 1

For many Americans, there is apparently a thin blue line between order and chaos. Breach it and untold furies lie beyond. The police require unconditional support when they are in combat; sins are understandable and forgivable when they occur in the stress of battle.

For others, of course, it is a quite different story. The police are a crude instrument of power, often failing to differentiate between criminals and bystanders and full of barely controlled aggressive impulses. Norman Mailer expresses this view eloquently in his description at the time of the 1968 Democratic Convention.

Every public figure with power, every city official, high politician, or prominent government worker knows in his unspoken sentiments that the police are an essentially criminal force restrained by their guilt, their covert awareness that they are imposters, and by a sprinkling of career men whose education, rectitude, athletic ability, and religious dedication make them work for a balance between justice and authority. ${ }^{2}$

This paper explores the sources of public support and opposition to police violence. The most highly publicized police violence of the last decade has

1. Reported in the San Francisco Chronicle, Wednesday, March 4, 1970.

2. Norman Mailer, Miami and the Siege of Chicago (Cleveland: World Publishing Co., 1968), p. 175 . taken place in a political context with the police confronting organized groups rather than isolated individuals. Since police frequently appear in such conflicts as protagonists, attitudes toward them are likely to be closely bound to support and opposition to the social movements that have occurred within American society during this period. Hence, we start with the more general issue of the nature of social movements before turning to the more specific phenomenon of attitudes toward the police.

\section{Support for Political Movements}

Two broad orientations run through efforts to understand the sources of support for such movements as the radical right, student activism, black power, and the like. One orientation has roots in the theory of mass society and views the recruitment to such movements as primarily reactive. Potential supporters presumably become available to a movement because they are supposed victims of social strains or personal anxieties. In addition, certain social controls are thought to be absent for these individuals, making them especially promising targets for mobilization by the leaders of mass movements.

The second orientation has roots in class or conflict group analyses and views the recruitment to these movements as more proactive. Rather than being acted upon, the participants are seen as goal-directed actors pursuing social change through collective action. At the risk of overdrawing the differences, we will attempt to sketch these two orientations as competing models.

\section{Reactive Model}

The reactive model is characterized by weak social attachments and personal vulnerability.

In this model, there are two steps leading to participation in mass movements. 
The first of these is the formation of an aggregate of individuals who are psychologically ready for participation. Readiness to participate comes from the absence of those conditions that constrain others from involvement in essentially irrational forms of political action. In this model, the mass movement participant presumably lacks the series of institutional affiliations and group loyalties that bind people into the political system and create loyalty to it. Those who are heavily embedded in such intermediate associations are less available for new loyalties. Those who are weakly attached and are peripheral to existing social networks are "loose" in the system. Being loose, there are few constraints preventing the development of support for proffered social movements.

Being unconstrained, however, is only part of the story. Mass movements must also promise to meet some important need to energize the unattached, potential recruit. Several different motivational bases have been suggested but, for our purposes, it is unnecessary to distinguish among them. We will use them here as examples of the same basic argument.

One might, for example, emphasize the personal anxiety that results from lack of strong social attachments. Participation in a mass movement provides the emotional satisfaction of being part of a group with strong solidarity-a satisfaction that the participant lacks prior to his participation. In this argument, participation in a movement fills an important psychological need of belongingness; Fromm and Hoffer write in this spirit. ${ }^{3}$

A structural example might empha-

3. Erich Fromm, Escape from Freedom (New York: Rinehart and Co., 1941); Eric Hoffer, The True Believer: Thoughts on the Nature of Mass Movements (New York: Harper \& Bros., 1951). size status insecurity. Individuals occupying marginal social positions may experience common strains as social change occurs. Among these groups losing status in society, it will be especially those individuals with weak and conflicting group loyalties who will manifest these strains to the greatest degree. Those with inconsistent statuses, for example, may find that their claims based on their higher status characteristic are no longer socially validated; at the same time, they reject the lower status group into which they are moving and the psychological support that it might provide. Hence, their social marginality gives them a special kind of psychological vulnerability. There are other potential sources of status insecurity besides that of objectively inconsistent statuses but the argument is, in general, similar: $\mathrm{By}$ the symbolism and the meaning they give his social condition, by their myth of a better future, by the camaraderie and group support they provide, mass movements supply some important satisfactions for the unattached and vulnerable individual. Kornhauser and many of the authors in The Radical Right argue along these lines. ${ }^{4}$

Note that the participants in mass movements are primarily reactive in this model. A major part of the dynamic of mobilization is supposed to be provided by elites and, in some cases, demagogues who skillfully exploit the vulnerabilities of the masses for their own political ends. The primary empirical implication of this argument is that degree of social attachment will be negatively associated with support for social movements. In addition, degree of insecurity about one's social identity and degree of

4. See especially Daniel Bell, Seymour Martin Lipset, and Richard Hofstadter in Daniel Bell, ed., The Radical Right (Garden City, N.Y.: Doubleday, 1964); and William Kornhauser, The Politics of Mass Society (New York: Free Press, 1959). 
social marginality should be positively associated with movement support.

\section{Proactive Model}

The proactive model is characterized by conflict groups and group identification.

The mechanisms invoked in this second model are much more conventional. Participation in a social movement is assumed to involve much the same process as group participation in general. Those most available for participation will be those who are not handicapped by constraints such as cross-pressures or social isolation. Thus, the more socially imbedded one is in a group, the more likely he is to become involved in a social movement that involves the group's interest.

Note the underlying assumptions here about social movements. They are seen to embody challenges by relatively powerless groups. These challenging groups are the activist portion of some underlying solidary group. They represent a constituency on behalf of whom they are attempting to change the society. Much of their effort centers on the mobilization of this constituency and its conversion into an active political force. This political struggle takes the form of a mass movement because the groups involved initially lack the scale of organization, access, and appropriate response to operate effectively inside the existing political arena. If they ultimately acquire such access and resources, their organizational strategy will shift from that of a mass movement to the tactics of conventional politics.

This model assumes, then, that if groups were equal in their access to resources and were all well integrated into the political system, there would be little occasion for collective action outside of institutional channels. To a greater or lesser degree in different societies, however, political integration is not uniform among social groups. Groups with less access forge their own instruments of change and, in American society, this often takes the form of a mass movement. Tilly, Gamson, and Rogin write in this spirit. ${ }^{5}$

The activists in this political struggle are those members of the challenging group that most strongly identify with and are most strongly embedded in the group. Those with the weakest group attachments will be less likely to be drawn into participation. In contrast with the previous model, this one is proactive; and the mass movement is viewed essentially as an instrumental form of organization by a group that lacks institutional power. The leaders are not "outsiders" who are using the movement for their own, separate purposes but "insiders" who embody the group's norms and values.

Thus, the empirical implications concerning group attachment contrast sharply with the first model. If a movement embodies a challenging group's interest, then the participants will tend to be those who are most strongly attached to the group. Those who are peripheral, who are socially isolated, cross-pressured, or otherwise marginal will be the least likely to participate in movement activities.

\section{McCarthyism, Goldwater Support, and Student Activism}

Both models may be helpful in explaining a given social movement, up to a point. Movements may change their

5. Charles Tilly, "From Mobilization to Political Conflict," multilith (Ann Arbor, Mich.: University of Michigan, 1970); William A. Gamson, Power and Discontent (Homewood, IIl.: Dorsey, 1968) and "Stable Unrepresentation in American Society," American Behavioral Scientist 12 (Nov.-Dec., 1968) 15-21; Michael Paul Rogin, The Intellectuals and McCarthy: The Radical Specter (Cambridge, Mass.: M.I.T. Press, 1967). 
character, appealing at one time to relative social isolates and at another to those with strong loyalties to a challenging group. Or, one wing of a complex movement may be best understood by one model while another part of it is handled by the other. Having conceded this, however, it is difficult for both to be generally correct, because they differ in their assumptions about the basic nature of the phenomenon being explained.

Take the case of McCarthyism in the early 1950's. Labeling McCarthy supporters as members of the "radical right" rather than as "conservative" invokes the first model. Bell, Hofstader, Lipset, and other students of Joe McCarthy's support emphasized status anxiety as the underlying cause of participation in the movement. ${ }^{6}$ "Communists in government" provided a psychologically rewarding (i.e., simplistic) conspiratorial explanation and scapegoat for the alleged insecurities and anxieties that the McCarthy followers were supposed to be experiencing.

Recently, however, Rogin has taken a fresh look at the McCarthy phenomenon and his analysis suggests that the proactive model is more appropriate. A close look at county voting records and at other evidence leads him to conclude that "McCarthy capitalized on popular concern over foreign policy, communism, and the Korean War, but the animus of McCarthyism had little to do with any less political or more developed popular anxieties. . . . McCarthy did not split apart an elite, the parts of which had been equally conservative before him. He rather capitalized on an existing liberal/conservative split within the existing Republican elite." ? Polsby's analysis of poll data points in the same general direction. Party

6. See Bell, op. cit.

7. Rogin, op. cit., pp. $216,220$. affiliation is the single best predictor of support for McCarthy-Democrats opposed him and Republicans supported him. ${ }^{8}$ Rogin concludes from his own review, "In these polls, as in the data reported by Polsby, no other single division of the population (by religion, class, education, and so forth) even approached the party split." 9

Rogin rejects the notion that McCarthy was sustained primarily by the vague discontents of frustrated groups. "McCarthy had powerful group and elite support. He did not mobilize the masses at the polls or break through existing group cleavages. . . . Communism and the Korean War played crucial roles." 10 Strange as it may seem, the issues on which McCarthy mobilized support were apparently real ones for his followers, not merely symbolic of private anxieties.

The first model is also a popular apparatus for explaining the support for Senator Goldwater in 1964. It was frequently assumed that the early supporters of Goldwater were anomic, institutionally detached "cranks," neofascists, or "infiltrators" into the Republican Party. "Little old ladies in tennis shoes" became the popular phrase to capture the lunatic fringe imagery.

McEvoy has demonstrated that the evidence sharply contradicts this image of the Goldwater phenomenon. ${ }^{11}$ Preconvention supporters of Goldwater were compared on a number of variables with those who ultimately voted for him even though they had preferred another nominee prior to the convention. The early Goldwater supporters were very

8. Nelson W. Polsby, "Toward an Explanation of McCarthyism," Political Studies 8 (October, 1960), 250-271.

9. Rogin, op. cit., p. 234.

10. Ibid., p. 268.

11. James C. McEvoy, Radicals or Conservatives? The Contemporary American Right (Chicago: Rand McNally, 1970). 
significantly higher on such variables as church attendance, income level, and education. They were more likely to be married. Furthermore, they were much higher in past participation in Republican Party politics. Finally, they exhibited average to low levels of objective status discrepancy. None of this evidence suggests lack of attachment; on the contrary, early Goldwater supporters seem to be strong conservatives with social support and respect from their friends and neighbors. ${ }^{12}$

The persistence of social science support for the reactive model in the absence of much data that support it suggests something about its ideological biases. It typically has a pejorative ring, suggesting that supporters of a political movement are irrationally seeking simple, illusory solutions for complex problems. Since social scientists who study right-wing movements are typically hostile to them, this model readily suggests itself and receives far less critical examination than it deserves.

When attention turns to movements of the left, there is much less tendency to invoke the reactive model. Although the McCone Commission Report on the Watts riot suggested that rioters were recent migrants with weak attachment to the community, social scientists were quick to test and demolish this hypothesis. ${ }^{13}$ Similarly, this model has failed to gain a foothold as an explanation of student activists. While popular articles about student "rebels" may have postulated their personal maladjustment, seri-

12. The weak attachment model might conceivably account for some "deviant" Goldwater supporters-that is, supporters from areas where few people were sympathetic.

13. See, for example, Nathan Caplan and Jeffery M. Paige, "A Study of Ghetto Rioters," Scientific American (August, 1968), 15-21, and Jeffery M. Paige, Collective Violence and the Culture of Subordination (Ph.D. diss., University of Michigan, 1968). ous studies put this myth to rest. Student activists, it turns out, are not the most marginal members of the student body but those most embedded in many aspects of life at the university. They are not academic failures, psychological wrecks, or social isolates, but those with better than average academic performance, with more liberal parents, with higher self-esteem, and with friends who have similar political views. They are, in short, well socialized and personally well-adjusted members of politically militant sub-groups in the university. ${ }^{14}$ We do not mean to imply here that activists are "typical" students, but merely that they are actively and centrally involved in life at the university -in fact, more so than the typical student.

In all the above studies, the evidence seems more nearly to support the proactive model. We would not argue that this is necessarily true for all recruits to social movements. But at this point, we would be skeptical any time the reactive model is invoked to explain a movement when the person who invokes it is far removed from or unsympathetic to the movement or the issue in question.

\section{MeASURING SUPPORT FOR Police Violence}

The models discussed above apply rather generally to social movements. The issue of police violence, we argue, must be viewed in this more general context. Police may play two different roles in group conflict situations. They may take a relatively neutral posture, remaining on the sidelines as much as possible and operating to make sure that the means of carrying on conflict remain

14. See the various articles in Edward E. Sampson, ed., Stirrings Out of Apathy: Student Activism and the Decade of Protest, special issue of the Journal of Social Issues 23 (July, 1967), for documentation of this point. 
within certain limits. Or, they may be used as a partisan instrument or ally of one group in the conflict. The latter role is especially likely when the conflict is between the authorities and those challenging them.

Our underlying concern in this paper is with the presence or absence of constraint on the use of police as a partisan instrument against challenging groups. One aspect of this constraint is the climate of opinion that is reflected in public attitudes toward police violence. By understanding where the sources of public support and opposition to police violence are located, we can understand something about the nature and strength of this possible source of constraint on police behavior. The two models discussed above, as we will argue shortly, have direct implications for this issue. Before considering this, we turn to a description of our data and our measure of support and opposition for police violence.

The data we report were obtained from a national cross-section probability sample of adult Americans conducted for the National Commission on the Causes and Prevention of Violence, by Louis Harris Associates of New York in October, $1968 .^{15}$ The sample consists of 1176 completed interviews and is more fully described in Kirkham, Levy, and Crotty, and McEvoy. ${ }^{16}$

The interview schedule contained a section of 25 statements about violence in various contexts--personal, political, international, and so forth. Respondents were asked to express varying de-

15. McEvoy served as special consultant to the Commission Task Force on Political Assassination.

16. James Kirkhan, Sheldon Levy, and William J. Crotty, Assassination and Political Violence, A Report to the National Commission on the Causes and Prevention of Violence (Washington, D.C.: U.S.G.P.O., 1969), and McEvoy, Radicals or Conservatives? op. cit. grees of agreement or disagreement with each statement. A factor analysis of the entire set identified several distinct clusters, including one that we have labeled "police violence." This factor showed high loadings on three items:

1. The police are wrong to beat up unarmed protestors, even when these people are rude and call them names. (Factor loading: .79)

2. The police frequently use more force than they need to when carrying out their duties. (Factor loading: .62)

3 . Any man who insults a policeman has no complaint if he gets roughed-up in return. (reversed item, Factor loading: .61).

The overall distribution on these three items is included in Table 1. A score on support for police violence was computed for each individual by reversing the direction of the third item and summing it with scores on the other two items. These total scores were then reduced to a seven-point scale, with high scores representing greater favorableness toward police violence. The distribution of the sample on this index is reported in Table 2 .

\section{Results}

Our attempts to explain the variation in the index of support for police violence will be guided by two models derived from the more general models described in the first section of this paper.

\section{Reactive Model}

In this argument, we suggest that police violence raises a fundamental question for our respondents: Do they see police as embodying the law, or as subject to its constraints like other citizens? To appreciate this second view, one must embrace a complex normative principle. Those who have allegiance to it resemble those who are usually 
TABle 1-Distribution of Responses to Items in Police Violence Index

\begin{tabular}{|c|c|c|c|c|c|}
\hline & \multicolumn{5}{|c|}{ Percentages } \\
\hline & $\begin{array}{l}\text { Strongly } \\
\text { AgreE }\end{array}$ & AGREE & Disagree & $\begin{array}{l}\text { StrongiLy } \\
\text { DisaGREE }\end{array}$ & $\begin{array}{l}\text { Don't } \\
\text { KNOW }\end{array}$ \\
\hline $\begin{array}{l}\text { The police are wrong to beat up } \\
\text { unarmed protestors, even when } \\
\text { these people are rude and call } \\
\text { them names. }\end{array}$ & $\underbrace{12}$ & 37 & 36 & 9 & 6 \\
\hline $\begin{array}{l}\text { The police frequently use more } \\
\text { force than they need to when } \\
\text { carrying out their duties. }\end{array}$ & 9 & 19 & 46 & 18 & 7 \\
\hline $\begin{array}{l}\text { Any man who insults a policeman } \\
\text { has no complaint if he gets } \\
\text { roughed-up in return. }\end{array}$ & $\underbrace{13}$ & 44 & 32 & 7 & 4 \\
\hline
\end{tabular}

found to support principles of civil liberties. This means, especially, those who are well educated and have other characteristics associated with high normative integration into the political system.

More specifically, this model implies the following hypotheses: ${ }^{17}$

1) The higher the educational level, the more opposition to police violence.

2) Assuming that whites are higher in normative integration than blacks, whites will be more opposed to police violence than blacks.

3) Registered voters will be more opposed to police violence than those who are not registered.

4) People who identify with a major political party will be more opposed to police violence than those who lack such identification.

\section{Proactive Model}

In this argument, the police violence index primarily taps trust in the police.

17. It implies many others beyond those stated here. However, we confine ourselves to those hypotheses that our data enable us to test.
During periods of sharp challenge to the distribution of power and privilege in a society, the police tend to be used as a partisan instrument in defense of privilege. When this happens, they usually become agents of established groups and opponents of challenging groups. Gamson defines trust in these terms: "Confidence in authorities means that they are perceived as the group's agents, that the group members identify with them. ... Alienation from authorities means that ... they are ... the agents of groups with conflicting goals." 18

The past decade has been a period of high conflict between challenging groups and authorities. Consequently, individuals will differ sharply in trust of the police, depending on whether they are part of groups attacking the established order or of groups defending it. Not only will group memberships determine attitudes toward the police, but the strength of group identifications and attachments will determine the degree of such support. ${ }^{10}$

18. Gamson, op. cit., pp. 54, 56.

19. Unfortunately, we lack the data to test this part of the argument here. 
More specifically, this model implies the following hypotheses:

1) Blacks will be more opposed to police violence than whites.

2) Young people will be more opposed to police violence than older people.

3) Poor people will be more opposed to police violence than rich people.

4) Financially dissatisfied people will be more opposed to police violence than financially satisfied people.

Table 3 presents a series of bivariate relationships between the police violence index and the variables suggested by the hypotheses listed above. It should come as no great surprise to most readers that race sharply differentiates toward police violence: blacks are much more likely to be against police violence than are whites. Furthermore, there is some additional evidence that this difference is not merely a reflection of general distrust of authority, but is more specifically directed at the police. The interview schedule contained a rather extreme item expressing political distrust: "The government in Washington is the enemy, not the friend, of people like me." Only 8 percent of the whites in the sample agree with this statement; and the percentage for blacks is identical. Thus, the great difference between blacks and whites on the police violence index seems to reflect attitudes toward this specific object of trust or distrust.

Education shows a moderate effect. As education increases, so does opposition to police violence, from 31 percent for those with less than a high school diploma to 45 percent for college graduates. Family income shows no simple relationship to police violence, but age does: the younger group shows more opposition. However, those who are financially most dissatisfied are higher in their opposition to police violence ( 42 percent) than are those who are happiest with their financial position (29 percent).

As for our measures of political involvement, Republican Party identifiers show the least opposition to police violence (25 percent); Democrats and those without a major party identification are more opposed (38 percent). Finally, those who are registered to vote show slightly less opposition to police violence ( 34 percent) than those who are not participants in the electoral process (40 percent).

A multivariate analysis adds some additional information. Chart 1 presents the interaction between education and race. The figures in this chart represent the percentage of respondents in each category who fall at the antiviolence end of the index (categories 0-2). Education has no additional effect for blacks; those at all educational levels are opposed to police violence. For whites, education has some explanatory power; the percentage of whites opposed to police violence increases from 19 in the lowest group to 43 in the highest but remains considerably short of the overall black figure of 70 .

Given the importance of race and of

TABLE 2--Degree of Support of Police Violence

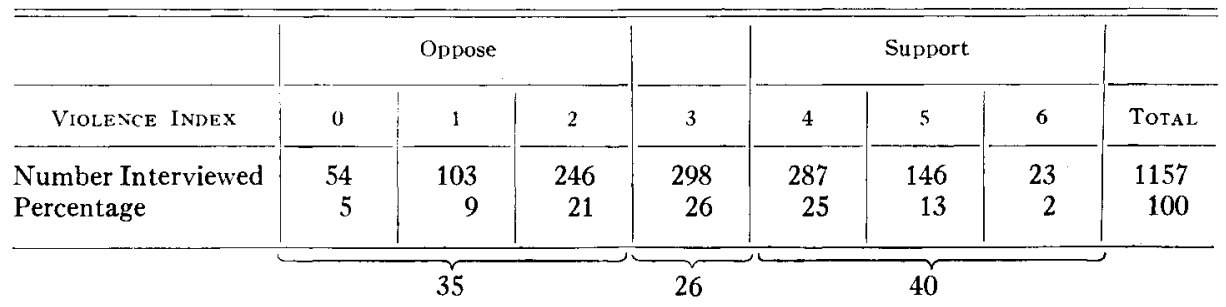


education for whites, Table 4 controls for these variables in exploring the relationship between the police violence index and several other relevant variables. Family income still shows no consistent relationship; at best, there is a slight suggestion that whites in the lowest income group are more opposed to police violence than their wealthier counterparts at each educational level. For blacks, the direction is reversed, and only 51 percent of those with income under $\$ 5,000$ fall at the oppose-police- violence end of the index. Financial satisfaction shows a similar but more pronounced relationship for whites-the least satisfied are most opposed to police violence at each educational level; there is no clear direction on this variable for blacks. Age differences emerge more sharply, particularly for the college group. Of white college graduates under 30 years of age, 58 percent oppose police violence compared to one-third of those over age 50 with similar education.

TABLE 3-Relationship of Selected Variables to Attitudes Toward Police VIolence

\begin{tabular}{|c|c|c|c|c|}
\hline RESPONDENTS & $\begin{array}{l}\text { OPPOSING } \\
\text { PoLICE } \\
\text { VIOLENCE* } \\
\text { Percentage }\end{array}$ & $\underset{\text { Percentage }}{\text { Mindie }}$ & $\begin{array}{l}\text { SuPPORTING } \\
\text { POLICE } \\
\text { VIOLENCE* } \\
\text { Percentage }\end{array}$ & $\underset{\text { INTERVIEWED }}{\text { NUMBER }}$ \\
\hline $\begin{array}{l}\text { Race } \\
\text { White } \\
\text { Black }\end{array}$ & $\begin{array}{l}27 \% \\
69 \%\end{array}$ & $\begin{array}{l}27 \% \\
18 \%\end{array}$ & $\begin{array}{l}46 \% \\
13 \%\end{array}$ & $\begin{array}{l}(929) \\
(215)\end{array}$ \\
\hline $\begin{array}{l}\text { Education } \\
\text { Not high school graduate } \\
\text { High school graduate but not } \\
\text { college graduate } \\
\text { College graduate }\end{array}$ & $\begin{array}{l}31 \% \\
36 \% \\
45 \%\end{array}$ & $\begin{array}{l}28 \% \\
24 \% \\
24 \%\end{array}$ & $\begin{array}{l}41 \% \\
40 \% \\
30 \%\end{array}$ & $\begin{array}{l}(488) \\
(542) \\
(125)\end{array}$ \\
\hline $\begin{array}{l}\text { Age } \\
\text { Under } 30 \\
30-49 \\
50 \text { or over }\end{array}$ & $\begin{array}{l}45 \% \\
40 \% \\
24 \%\end{array}$ & $\begin{array}{l}25 \% \\
23 \% \\
28 \%\end{array}$ & $\begin{array}{l}30 \% \\
37 \% \\
48 \%\end{array}$ & $\begin{array}{l}(276) \\
(417) \\
(447)\end{array}$ \\
\hline $\begin{array}{l}\text { Family Income } \\
\text { Under } \$ 5000 \\
\$ 5000-\$ 9,999 \\
\$ 10,000 \text { and above }\end{array}$ & $\begin{array}{l}36 \% \\
36 \% \\
34 \%\end{array}$ & $\begin{array}{l}29 \% \\
24 \% \\
26 \%\end{array}$ & $\begin{array}{l}36 \% \\
40 \% \\
40 \%\end{array}$ & $\begin{array}{l}(222) \\
(361) \\
(572)\end{array}$ \\
\hline $\begin{array}{l}\text { Financial Satisfaction } \\
\text { "Not satisfied at all" } \\
\text { "More or less satisfied" } \\
\text { "Pretty well satisfied" }\end{array}$ & $\begin{array}{l}42 \% \\
36 \% \\
29 \%\end{array}$ & $\begin{array}{l}22 \% \\
27 \% \\
27 \%\end{array}$ & $\begin{array}{l}37 \% \\
37 \% \\
44 \%\end{array}$ & $\begin{array}{l}(257) \\
(473) \\
(425)\end{array}$ \\
\hline $\begin{array}{l}\text { Party Identification } \\
\text { Republican } \\
\text { Democratic } \\
\text { Independent, other, or none }\end{array}$ & $\begin{array}{l}25 \% \\
38 \% \\
39 \%\end{array}$ & $\begin{array}{l}29 \% \\
25 \% \\
27 \%\end{array}$ & $\begin{array}{l}46 \% \\
38 \% \\
35 \%\end{array}$ & $\begin{array}{l}(288) \\
(576) \\
(238)\end{array}$ \\
\hline $\begin{array}{l}\text { Voting Registration } \\
\text { Registered } \\
\text { Not registered }\end{array}$ & $\begin{array}{l}34 \% \\
40 \%\end{array}$ & $\begin{array}{l}26 \% \\
26 \%\end{array}$ & $\begin{array}{l}41 \% \\
35 \%\end{array}$ & $\begin{array}{l}(919) \\
(235)\end{array}$ \\
\hline
\end{tabular}

* This column includes those in categories $0-2$ in Table 2 , the middle column contains category 3 , and the third column combines categories 4-6. 
CHART 1

Race and Education by Police

VIOLENCE INDEX

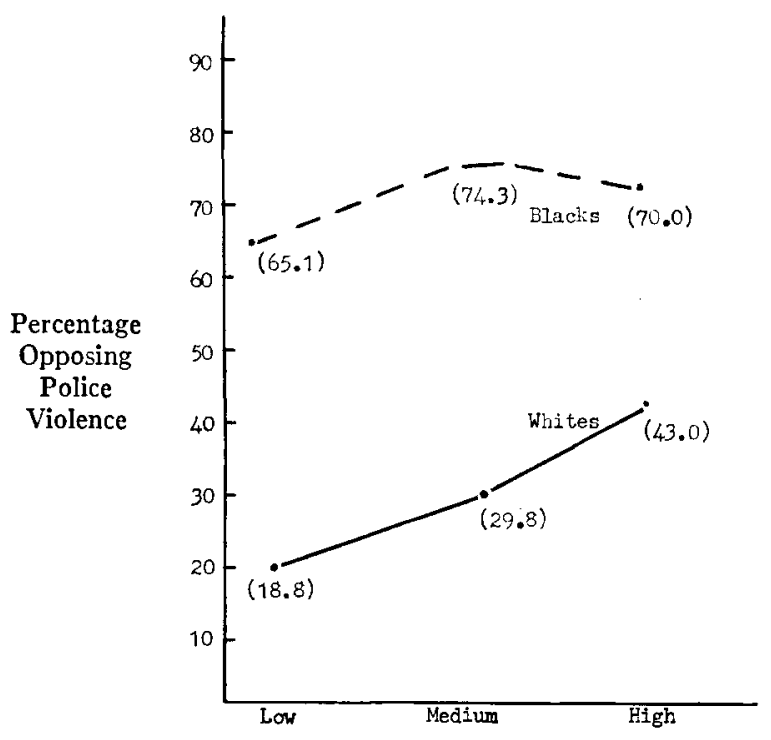

Educational Levei

The earlier results on party identification and voting registration emerge more clearly with race and education controlled. Those without a major party identification have the greatest opposition to police violence, while Republican identifiers show the lowest opposition. ${ }^{20}$ Furthermore, whites who are registered to vote are less likely to oppose police violence than those of the same educational level who are not registered voters. For blacks, this relationship is reversed.

\section{INTERPRETATION}

How well do our two models handle these results? The first model fares rather badly. It successfully predicts the positive relationship between education and opposition to police violence. However, it is not clear from this model why blacks, who most would argue are less normatively integrated, are so much

20. There are no differences on this variable, however, for low education whites. higher on opposition to police violence. It seems reasonable to assume that registering to vote is a mark of integration into the political system. If 50 , it is not clear from this model why those who are not registered to vote should be more opposed to police violence. The argument for the effects of major party identification is similar; but those who lack such identification are, if anything, more opposed to police violence.

The second model does considerably better. As predicted, blacks are more opposed to police violence than whites. Young college-educated whites are more opposed than other whites. The hypothesis concerning poor people receives equivocal support at best, with subjective satisfaction proving a better predictor than actual income. Perhaps the have/have-not dimension of conflict is less relevant at this time than the racial dimension.

By and large, then, the proactive 
Table 4-Percentage of People Interviewed Opposing Police Violence by Selected VARtables CONTROLleted FOR

RACE AND EDUCATION FOR WHITES

\begin{tabular}{|c|c|c|c|c|}
\hline & \multirow[b]{2}{*}{ В L.aсks } & \multicolumn{3}{|c|}{ Whites } \\
\hline & & $\begin{array}{c}\text { Not HS } \\
\text { GRADCATE }\end{array}$ & $\begin{array}{c}\text { HS GRADUATE } \\
\text { BUT NoT } \\
\text { COLLEGE } \\
\text { GRADUATE }\end{array}$ & $\begin{array}{c}\text { COLLEGE } \\
\text { GRADCATIE }\end{array}$ \\
\hline \multicolumn{5}{|l|}{ Age } \\
\hline Under 30 & $70 \%(64)$ & $31 \%(35)$ & $34 \%(141)$ & $58 \%(36)$ \\
\hline $30-49$ & $77 \%(82)$ & $24 \%(93)$ & $32 \%(193)$ & $41 \%(49)$ \\
\hline 50 or over & $56 \%(68)$ & $15 \%(224)$ & $22 \%(126)$ & $28 \%(29)$ \\
\hline \multicolumn{5}{|l|}{ Family Income } \\
\hline Under $\$ 5000$ & $51 \%(63)$ & $22 \%(104)$ & $35 \%(48)$ & $71 \%(7)$ \\
\hline$\$ 5000-\$ 9999$ & $75 \%(88)$ & $17 \%(132)$ & $30 \%(115)$ & $35 \%(23)$ \\
\hline$\$ 10,000$ and above & $71 \%(68)$ & $19 \%(122)$ & $29 \%(293)$ & $46 \%(79)$ \\
\hline \multicolumn{5}{|l|}{ Financial Satisfaction } \\
\hline "Not at all" & $63 \%(75)$ & $27 \%(73)$ & $32 \%(94)$ & $57 \%(14)$ \\
\hline "More or less" & $74 \%(87)$ & $20 \%(136)$ & $29 \%(194)$ & $46 \%(46)$ \\
\hline "Pretty well" & $69 \%(52)$ & $13 \%(141)$ & $30 \%(172)$ & $35 \%(52)$ \\
\hline \multicolumn{5}{|l|}{ Party Identification } \\
\hline Republican & $56 \%(18)$ & $18 \%(88)$ & $24 \%(135)$ & $31 \%(42)$ \\
\hline Democrat & $69 \%(169)$ & $18 \%(183)$ & $28 \%(187)$ & $47 \%(32)$ \\
\hline Independent, other, none & $88 \%(17)$ & $18 \%(62)$ & $38 \%(117)$ & $51 \%(39)$ \\
\hline \multicolumn{5}{|l|}{ Voting Registration } \\
\hline Registered & $72 \%(153)$ & $17 \%(273)$ & $27 \%(375)$ & $42 \%(105)$ \\
\hline Not registered & $60 \%(60)$ & $24 \%(79)$ & $38 \%(81)$ & $56 \%(9)$ \\
\hline
\end{tabular}

Percentages include those who fall at the anti-police-violence end of the index (categories 0-2); the number next to the percentage refers to the total number of respondents with the specified characteristic.

model makes good sense of our data. There is one exception to this success, and an important one: it fails to account for the effect of education. To the extent that education is solely a measure of privilege, increasing it should make one more supportive of police violence rather than less so. This hypothesis not only fails to be supported but, as Table 4 indicates, education has an effect on white attitudes even when income is controlled. This suggests that, as we might expect, there is something about education other than the privilege it brings that may be contributing to attitudes toward police violence. How, then, can this model be enlarged to account for this additional result?

Each model treats education as an indicator of something else-of social integration (in the reactive model), or of privilege (in the proactive model). But perhaps it has an effect in its own right, through influencing the conceptual sophistication of the respondent. The more highly educated the respondent, the greater his cognitive differentiation between the police and the law. A highly educated respondent who is generally opposed to contemporary challenging groups may give his fealty to a more abstract conception of the law. 
Transgressors should be treated harshly but with due process; the legal system, not the police, is the proper bulwark against extra-legal dissidence.

This conception leads to recognition that not only the control of dissidents but also the control of the police can become a problem. Mailer describes the reactions to police behavior in the streets of Chicago at the time of the 1968 Democratic convention:

What staggered the delegates who witnessed the [police] attack . . . on Michigan avenue was that it opened the specter of what it might mean for the police to take over society. They might comport themselves in such a case not as a force of law and order, not even as a force of repression upon civil disorder, but as a true criminal force, chaotic, improvisational, undisciplined, and finally-sufficiently aroused-uncontrollable. ${ }^{21}$

Education, we suggest, gives enough of a glimpse of this specter to sober the sympathetic attitudes toward the police that the sophisticated "law and order" supporter may have. We argued earlier that the police violence index taps trust in the police, and this trust is primarily a function of privilege. For respondents with low trust in the police-blacks, for example-the education factor is largely irrelevant, because differentiating between police and the law does not make them any more trusting toward the police. Respondents with high trust in the police but low education do not have their support for police violence inhibited by awareness of the police control issue. But as education increases for high trust respondents, this additional factor becomes more salient; their inclination to support police violence is retarded by their greater awareness of the problem of controlling the police.

21. Mailer, op. cit., p. 175.

\section{Conclusion}

Police comportment has an important effect on the degree of violence with which political conflicts are waged by challenging groups. As Stinchcombe argues,

Military control and liberty function together to stabilize political conflict. If the violent means of conflict are made much more expensive by effective enforcement by the police and army, while nonviolent means are made cheaper by the condition of liberty, then a rational organizational leader. . . will prefer less violent means. If the police and army are either ineffective, or enter into the conflict as full-fledged participants themselves by denying not only the right to riot but also the right to speak, then the comparative effectiveness of violent means in the competitive struggle increases, while the effectiveness of nonviolent means declines. Under these conditions, a rational organizational leader will choose a higher proportion of violent means. ${ }^{22}$

It is important to ask what constraints exist on the use of police as a partisan instrument or ally of one group in a conflict situation. Some of these constraints may be structural, including both aspects of internal police organization and linkages between the police and political, economic, and other organizations. This paper does not address these possible structural constraints but it does raise the question of normative constraints on police behavior. If police violence violates widely held norms in American society, then a public outcry against such behavior might serve to constrain it and to mobilize institutional pressure against it.

We find scant cause for optimism

22. Arthur L. Stinchcombe, "Social Structure and Organizations," in James G. March, ed., Handbook of Organizations (Chicago: Rand McNally, 1965), p. 176. 
about any constraint from public opinion. Robinson describes what a sample of 1,005 respondents thought about police action at the Chicago convention in $1968 .^{23}$ Only 19 percent believed that the police had used too much force; 25 percent felt that they had not been forceful enough, and the rest were either satisfied with the amount of force used or had no opinion.

Our own data have the same thrust. With the possible exception of the effect of education, we have not found any

23. John P. Robinson, "Public Reaction to Political Protest: Chicago 1968," Public Opinion Quarterly 34 (Spring 1970), 1-9. support for the proposition that police violence seriously violates American political norms. Extra-legal police actions directed against unpopular targets are unlikely to draw censure or even disapproval from those substantial segments of the American public for whom the police are the "good guys." And for those who, like ourselves, see police participation in conflicts in a partisan role as an invitation to counter-violence on the part of challenging groups, we offer this warning: Nurture whatever organizational and structural constraints exist, for you will find few normative constraints in the present American political culture. 